\title{
Fine evaluation and favorable area prediction of deep source rocks in northern Songliao Basin
}

\author{
Fan Zhang ${ }^{1,2}$, Yanjie $\mathrm{Li}^{1,2}$, Xiaoshan $\mathrm{Ji}^{1,2}$, Qiuli Huo ${ }^{1,2}$, Yuming $\mathrm{Wu}^{1,2}$, Yitong Wang ${ }^{1,2}$, Zhigao Ren ${ }^{1,2}$, and Junchi Bao ${ }^{1,2}$ \\ ${ }^{1}$ Exploration and Development Research Institute of Daqing Oilfield Co., Ltd., 163712 Daqing Heilongjiang, China \\ ${ }^{2}$ Key Laboratory of tight oil and shale oil accumulation of Heilongjiang province, 163712 Daqing Heilongjiang, China
}

\begin{abstract}
Focusing on Xujiaweizi fault depression, the geological conditions and geochemical characteristics of deep natural gas formation in the north of Songliao basin are evaluated, the natural gas resources are estimated, and the favorable areas are optimized. Shahezi Formation shale is a set of coal bearing sediments with high organic matter abundance (TOC is $1 \% \sim 12 \%$ ), high over maturity $\left(\mathrm{R}_{\mathrm{o}}\right.$ is $1 \% \sim 4 \%$ ) and shore shallow lake facies, which are mainly distributed in Xujiaweizi fault depression, Gulong-Lindian fault depression and Yingshan fault depression. The thickness, TOC, $\mathrm{R}_{0}$ and hydrocarbon generation of four thirdorder sequences with different lithology (mudstone and coal) are carefully evaluated for the Shahezi Formation shale in the deep layer of Songbei. The comprehensive evaluation shows that the mudstone thickness of Es4 member in Anda and Xuzhong areas of Xujiaweizi fault depression is large $(150 \sim 525 \mathrm{~m})$, TOC is high $(1 \% \sim 4 \%)$, thermal evolution degree is high $\left(\mathrm{R}_{\mathrm{o}}\right.$ is $\left.1.2 \% \sim 3.4 \%\right)$, and gas generation intensity is high $\left.(20 \sim 815) \times 108 \mathrm{~m}^{3} / \mathrm{t}\right)$, moderate buried depth $(3000 \sim 4500 \mathrm{~m})$ and overlapping area of $756 \mathrm{~km}^{2}$. It is a favorable exploration area for natural gas and shale gas in Daqing Oilfield.
\end{abstract}

\section{Deep geological features in Songbei}

The deep strata in the north of Songliao Basin mainly include lower Cretaceous Huoshiling formation, Shahezi formation, Yingcheng formation and Denglouku formation from bottom to top. The basement is Carboniferous Permian (Fig. 1), belonging to volcanic eruption and clastic rock coal bearing deposition in fault depression period. Among them, the coal mudstone of Shahezi formation dominated by shore shallow lake facies is thick, with good hydrocarbon generation conditions and great resource potential. Among them, the coal mudstone of Shahezi Formation dominated by shore shallow lake facies is thick, with good hydrocarbon generation conditions and great resource potential. Among them, Xujiaweizi has discovered the Xushen gas field in the volcanic rocks of the Yingcheng formation, and has obtained industrial gasflow in several sets of formations such as Shahezi and Denglouku formations. There are also many exploratory wells that have seen oil and gasd in Gulong-Lindian fault depression in the west and the Yingshan fault depression in the east [1-3].

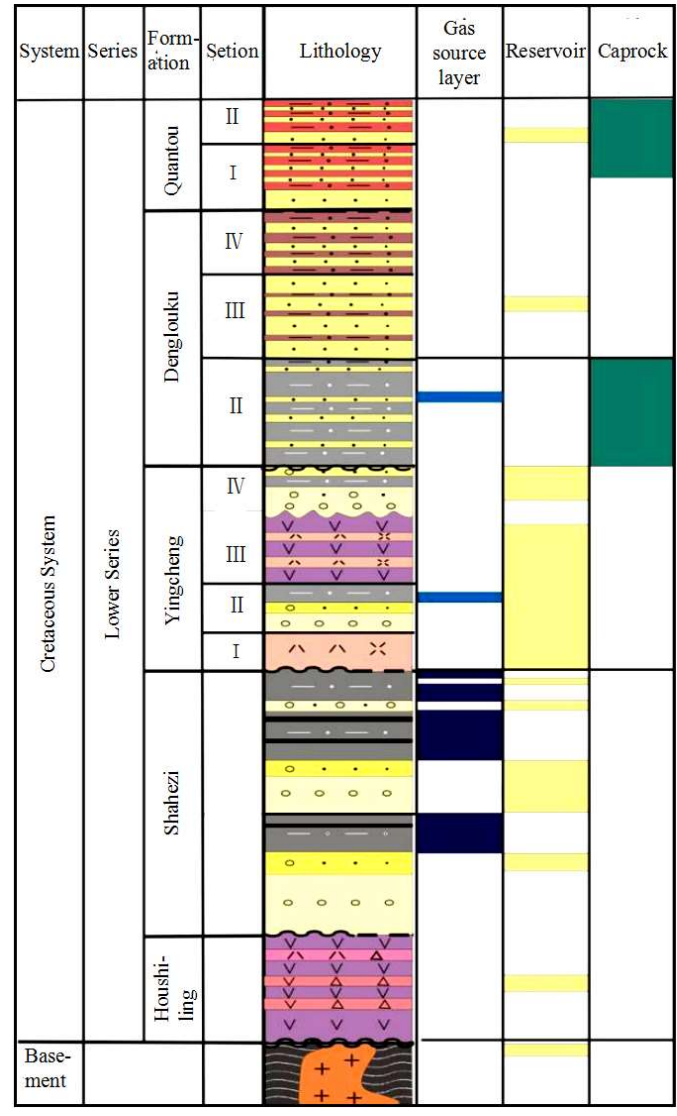

Fig. 1. Comprehensive column section of deep layer in northern Songliao Basin.

\footnotetext{
* Corresponding author: zhangfan1@Petrochina.com.cn
} 


\section{Geochemical characteristics of deep source rocks in Songbei}

The abundance of organic matter in gas-bearing shale not only determines the amount of shale gas generation, but also affects the occurrence and enrichment of shale gas, which in turn influences the resource abundance of shale gas [4]. For thermogenic shale gas reservoirs, with the increase of shale $\mathrm{R}_{0}$, when $\mathrm{R}_{0}>1.1 \%$, shale oil begins to crack and generate gas; when $R_{0}>3 \%$, the volume of gas generation is significantly reduced [5], moreover, the large reduction of organic matter is not conducive to the formation of adsorbed gas. Therefore, the range of $\mathrm{R}_{\mathrm{o}}$ value of $1.1 \% \sim 3 \%$ is a favorable distribution area for thermally derived natural gas reservoirs. In this study, four sets of source rocks of deep Huoshiling formation, Shahezi formation, Yingcheng formation and Denglouku formation were systematically analyzed and evaluated from three aspects of abundance, type and maturity in the north of Songliao Basin. In terms of region, the organic abundance index of Xujiaweizi fault depression located in the northern and central part of Songliao basin is higher than that of gulong, Yingshan and other peripheral fault depressions (Fig. 1). From the horizon, the geochemical index of Shahezi formation shale is better than other horizons as a whole (Table 1).

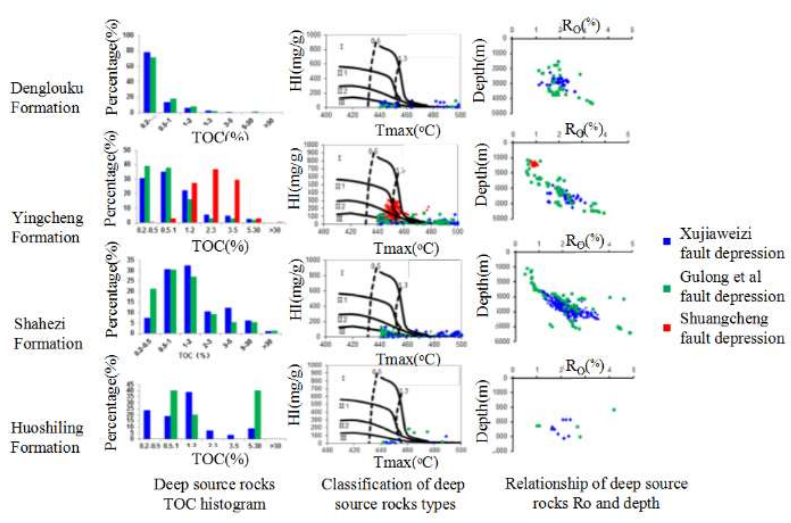

Fig. 2. Geochemical comprehensive evaluation map of deep source rocks in northern Songliao Basin.

Table 1. Evaluation table of geochemical characteristics of deep source rocks in northern Songliao Basin.

\begin{tabular}{|c|c|c|c|}
\hline Formation & TOC & Type & $\mathrm{R}_{\mathrm{o}}$ \\
\hline Denglouku & $\begin{array}{c}0.20 \% \sim 3.70 \% \\
(0.48 \%)\end{array}$ & III & $\begin{array}{c}1.13 \% \sim 2.62 \% \\
(1.94 \%)\end{array}$ \\
\hline Yingcheng & $\begin{array}{c}0.21 \% \sim 14.25 \% \\
(1.14 \%)\end{array}$ & $\begin{array}{c}\text { II } \sim \\
\text { III }\end{array}$ & $\begin{array}{c}1.50 \% \sim 3.14 \% \\
(2.25 \%)\end{array}$ \\
\hline Shahezi & $\begin{array}{c}0.2 \% \sim 76.6 \% \\
(2.62 \%)\end{array}$ & $\begin{array}{c}\text { II } \sim \\
\text { III }\end{array}$ & $\begin{array}{c}1.07 \% \sim 3.56 \% \\
(2.22 \%)\end{array}$ \\
\hline Huoshiling & $\begin{array}{c}0.20 \% \sim 26.19 \% \\
(2.11 \%)\end{array}$ & III & $\begin{array}{c}1.62 \% \sim 2.39 \% \\
(2.01 \%)\end{array}$ \\
\hline
\end{tabular}

*Minimum Maxmux (Average)

\section{Fine geochemical evaluation of deep source rocks in Songbei}

As the main component of natural gas generation and occurrence, a certain thickness of gas-bearing shale is the basic condition for the formation of natural gas enrichment areas, and it is also one of the important factors influencing the abundance of natural gas resources. The greater the thickness of shale rich in organic matter, the larger the scale of gas-bearing shale. At the same time, it can meet the needs of large-scale fracturing transformation and large-scale development of natural gas. When the thickness of gas bearing shale and the abundance of organic matter are determined, the area of gas bearing shale determines the amount of natural gas resources [6].

Due to the limited analysis data of core samples and the continuous formation information provided by logging data, organic matter has specific logging response because of its inherent physical and chemical properties. In recent years, a variety of logging combined evaluation methods have emerged: Based on the response characteristics of organic matter to sound wave, resistivity, density and natural gamma, an interpretation model is established to calculate the organic carbon value [7]. In this study, the $\Delta$ LOG method was used to accurately evaluate the total TOC of 137 exploratory wells in five fault depressions in the northern Songliao Basin, and effectively predict the total organic matter of source rocks in this area. Taking Well DS17 as an example, the average TOC of the source rocks of the four members of the Shahezi Formation is $4.93 \%$, and the thickness of "mud-coated sand" interval is greater than $30 \mathrm{~m}$, which has the geological conditions for forming of self-generating and self-storing natural gas [8] (Figure 3). On this basis, in order to meet the needs of fine research and source rock feature evaluation, this study made a fine comparison of the source rocks of the Shahezi Formation in Xujiaweizi. The results show that three cycles of high-quality source rocks can be developed in each sequence set of Shahezi Formation, in which the TOC value of Shahezi Formation source rocks in the north of Xujiaweizi fault depression is mainly $1 \% \sim 3 \%$, and the TOC value of some wells is greater than $3 \%$. It is describedthat the source rocks of Shahezi Formation in the north of Xujiaweizi fault depression are getting better and better in abundance and thickness from north to south from the TOC well connection profile of source rocks of well DS3-SS6 (Fig. 4). High quality source rocks are principally distributed in Anda area, which is generally characterized by high abundance and good continuity of Sha4 member. 


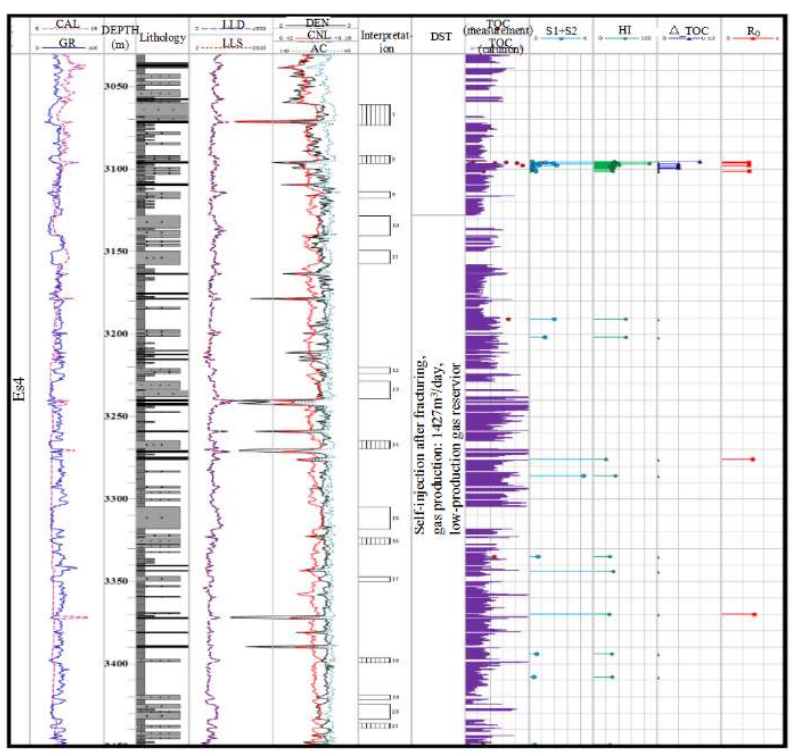

Fig. 3. Comprehensive histogram of Shahezi Formation in well DS17.

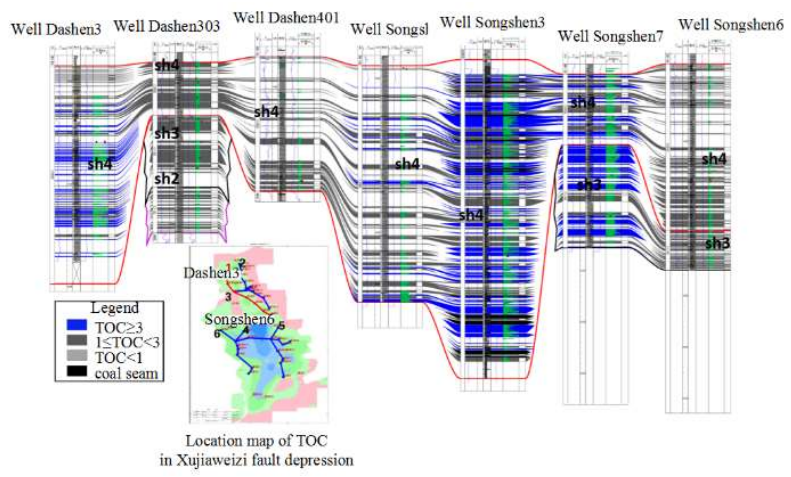

Fig. 4. TOC profile of Shahezi Formation source rocks in well DS3-SS6.

Based on the fine evaluation of single well and connected well of source rock, we calculate TOC results (removing oil-base mud pollution) and $\mathrm{R}_{\mathrm{o}}$ according to all exploratory wells, mud logging, lithology, and well logging, besides draw the mudstone thickness map, TOC plane (Fig. 6) and $\mathrm{R}_{\mathrm{o}}$ plane (Fig. 7) of the four sequences $(\operatorname{sh} 1, \operatorname{sh} 2, \operatorname{sh} 3, \operatorname{sh} 4)$ of the source rocks of the Shahezi Formation in the Xujiaweizi fault depression, referring to the formation thickness and sedimentary facies trend (Fig. 5).

It can be seen from the figure that the distribution trend and characteristics of the thickness, abundance and maturity of the source rocks of Shahezi Formation in the four vertical sequences are not different, and the plane distribution characteristics are also similar, indicating that the sedimentary center of this area is stable, multi cycle high-quality source rocks are developed, and the overall performance is relatively high abundance coal bearing source rocks, of which SH4 layer is the best. Abundance of organic matter in the source rocks of the Shahezi Formation in Xujiaweizi is mainly distributed between $0.5 \%$ and $5.0 \%$ of the TOC classification thickness map.
Among them, the TOC value is mainly $1.0 \%$ to $2.0 \%$, accounting for about $50 \%$ of the mudstone thickness of the whole Shahezi Formation.

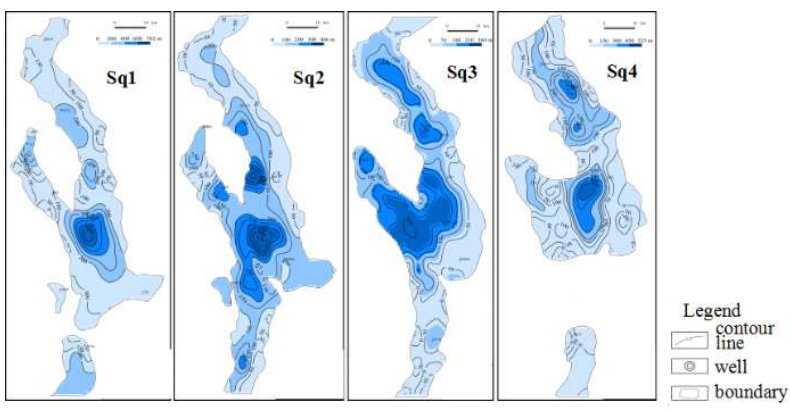

Fig. 5. Comparison map of mudstone thickness of four sequences of sourcerocks in Shahezi Formation of Xujiaweizi fault depression.

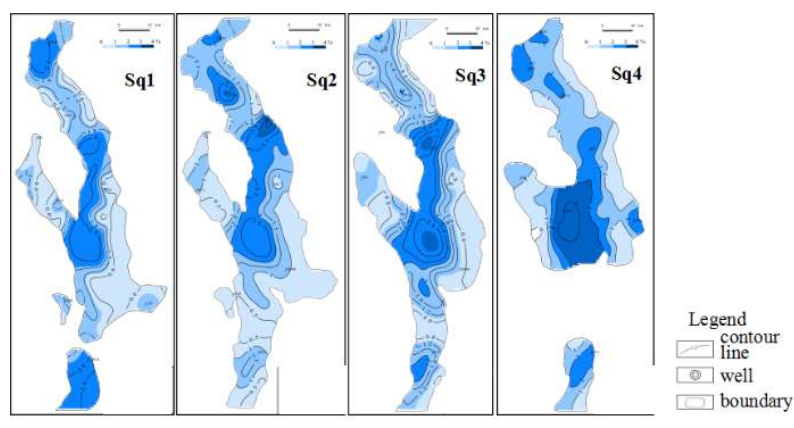

Fig. 6. TOC distribution comparison map of four sequence mudstone of Shahezi Formation in Xujiaweizi fault depression

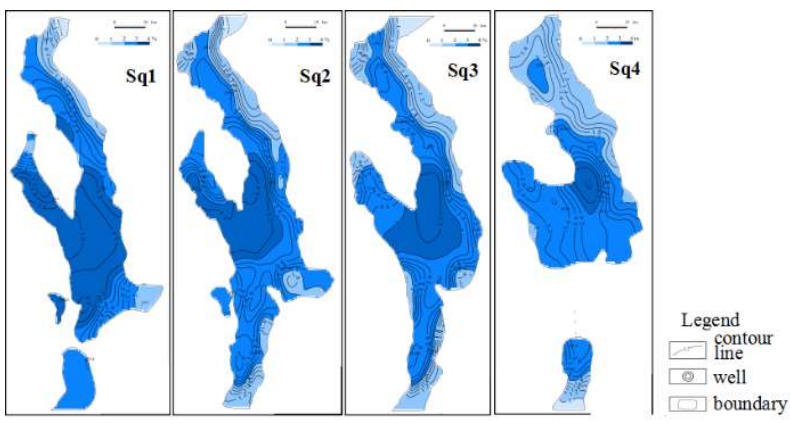

Fig. 7. Ro comparison map of sourcerocks of four sequences of Shahezi Formation in Xujiaweizi fault depression

\section{Deep natural gas resource potential and favorable area optimization in Songbei}

According to the latest drilling and seismic data, the mudstone thickness map is predicted, and the TOC value is calculated by logging curves, the measured $R_{0}$ value is corrected for the thermal history, and the gas generation volume of the subdivision layer is calculated by the genetic method (Table 2), The calculation results show that the proportion of gas generation of four sets of source rocks is Shahezi Formation $>$ Yingcheng Formation $>$ Huoshiling formation $>$ Denglouku formation. The gas generation intensity of source rocks in Shahezi Formation is high, more than 20 in most areas $\times 108 / \mathrm{km}^{2}$, which 
can form large and medium-sized gas fields [9 12] (Fig. 8).

Table 2. Calculation table of gas generation proportion of subdivision layers in Xujiaweizi fault depression.

\begin{tabular}{|c|c|c|c|c|}
\hline Formation & $\begin{array}{c}\text { Thickness } \\
\text { of source } \\
\text { rocks }\end{array}$ & $\begin{array}{c}\text { TOC } \\
(\%)\end{array}$ & $\begin{array}{c}\text { Gas } \\
\text { generation } \\
\left(10^{2} \mathrm{~m}^{2}\right)\end{array}$ & $\begin{array}{c}\text { Percentage } \\
(\%)\end{array}$ \\
\hline Denglouku & $0 \sim 200$ & 0.36 & 1805 & 0.61 \\
\hline Yingcheng & $0 \sim 300$ & 0.78 & 9361 & 3.16 \\
\hline $\begin{array}{c}\text { Es4 } \\
\text { mudstone }\end{array}$ & $0 \sim 600$ & 1.63 & 52626 & 17.78 \\
\hline $\begin{array}{c}\text { Es4 coal } \\
\text { seam }\end{array}$ & $0 \sim 80$ & 60 & 19004 & 6.42 \\
\hline $\begin{array}{c}\text { Es3 } \\
\text { mudstone }\end{array}$ & $0 \sim 300$ & 1.39 & 44531 & 15.05 \\
\hline $\begin{array}{c}\text { Es3 coal } \\
\text { seam }\end{array}$ & $0 \sim 60$ & 55 & 14522 & 4.91 \\
\hline $\begin{array}{c}\text { Es2 } \\
\text { mudstone }\end{array}$ & $0 \sim 500$ & 1.53 & 61097 & 20.64 \\
\hline $\begin{array}{c}\text { Es2 coal } \\
\text { seam }\end{array}$ & $0 \sim 45$ & 53 & 7959 & 2.69 \\
\hline $\begin{array}{c}\text { Es1 } \\
\text { mudstone }\end{array}$ & $0 \sim 800$ & 1.19 & 72056 & 24.35 \\
\hline $\begin{array}{c}\text { Es1 } \\
\text { coal seam }\end{array}$ & $0 \sim 60$ & 57 & 9596 & 3.24 \\
\hline $\begin{array}{c}\text { Huoshiling } \\
\text { In total }\end{array}$ & $0 \sim 100$ & 0.72 & 3399 & 1.15 \\
\hline
\end{tabular}

Fig. 8. Shale gas generation intensity plan of Shahezi

Formation in Xujiaweizi fault depression

Since the main part of shale gas is adsorbed gas, according to the principle of hydrocarbon generation and expulsion, part of the natural gas that not discharged but adsorbed in the source rock occupies the main source of shale gas. According to Pepper (1995), the gas adsorption coefficient is 0.02 , and in the middle of the fault depression, the hydrocarbon generation intensity is more than $100 \times 10^{8} / \mathrm{km}^{2}$ which has shale gas resource potential.

The favorable natural gas area with TOC $>2 \%$ of mudstone in $\mathrm{n}$ the fourth section of Shahe in Xujiaweizi fault depression is $756 \mathrm{~km}^{2}$ and $\mathrm{R}_{\mathrm{o}}$ is $1.1 \% \sim 4.0 \%$, which has good natural gas resource potential; Shahezi Formation mudstone has high gas generation intensity, ranging from 100 to $815 \times 108 / \mathrm{km}^{2}$ in the Anda and Xuzhong areas (Fig. 9). The measured porosity of 9 shale samples is $1.2 \% \sim 5.3 \%$, and the buried depth is $3000 \sim$ $4500 \mathrm{~m}$, which is a favorable exploration area for natural gas and shale gas in the next step [13 16]. 


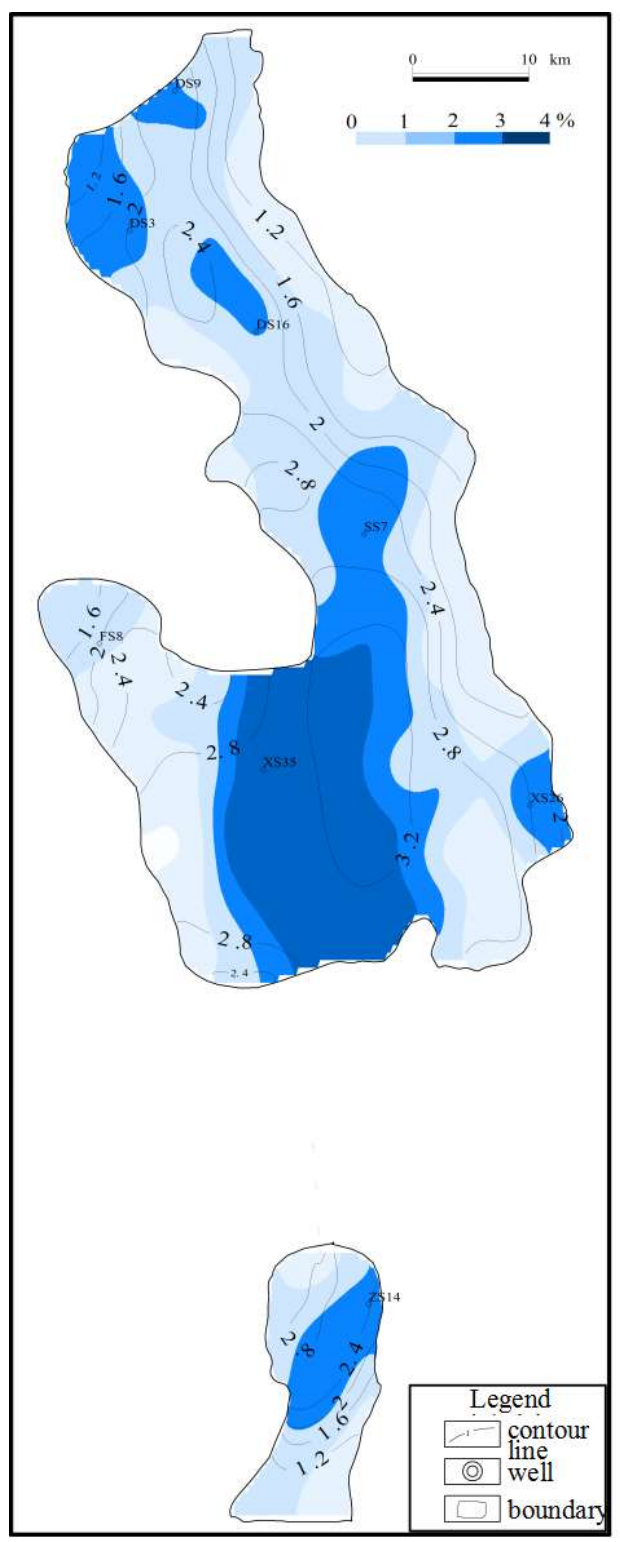

Fig. 9. Superposition of Ro and TOC of mudstone in the fourth member of Shahejie Formation inXujiaweizi fault depression.

\section{Conclusion}

1)Shahezi Formation develops coal-bearing sedimentary shale dominated by shore-shallow lacustrine facies, with high abundance and over-mature organic matter. It is the main source rock layer in the deep northern Songliao Basin, mainly distributed in the Xujiaweizi fault depression;

2)The gas generation of mudstone in Xujiaweizi fault depression is dramatically higher than coal gas generation. The mudstone gas generation volume of the first, second, third and fourth members of the Shahezi Formation is similar, and the mudstone of the fourth member of Shahezi Formation accounts for the largest proportion due to the highest maturity;

3) The fourth member of Shahezi Formation in Xujiaweizi fault depression has large mudstone thickness, high abundance and continuous distribution. Anda and Xuzhong, e.g. areas have moderate burial depths, which are favorable exploration areas for natural gas and shale gas in the next step of the Daqing Oilfield.

\section{References}

1. Feng Z. Q., Exploration potential of large Qingshen gas field in the SongliaoBasin $[\mathrm{J}]$. Natural Gas Industry, 26(6):1-5 (2006) .

2. Zhang F. et al, Study on geochemical characteristics andResource potential of coal measures source rocks in Daqing exploration area [R]. Daqing Oilfield Co., Ltd., Daqing, Heilongjiang, 1-51 (2014).

3. Wang W. G., et al, Gas generation characteristics and resource potential of the deepsourcerock in Xujiaweizi fault depression, northern Songliao Basin[J]. Natural Gas Geoscience, 25(7):1011-1018 (2014).

4. Chen S. Y., Liu H. J., Carboniferous Permian lithofacies and paleogeography in the eastern part of the north china platform [J]. Regional Geology of China, 16(4):379-386 (1997).

5. Xie D. N., Zhou L. F., Discussion on hydrocarbon generation potential and secondary hydrocarbon generation of organic matter from PermoCarboniferous coal measures in the southern North China [J]. Coal Geology \& Exploration, 34(1):30-34 (2006).

6. Ren Z. L., Tectonic and thermal evolution history of sedimentary basins in northern China[M]. Beijing:Petroleum Industry Press, 6-42 (1999).

7. Yan J.P., Liang Q., Geng B., et al, Log calculation method of geochemical parameters of lacustrine shale and its application: a case of lower Es3 in Bonan subsag, ZhanhuaSag. Lithologic Reservoirs, 29(4):108-116 (2017).

8. Fu W., Hou H.S., Zhang J. D., Liu C., Feng X., Lu.W., Structural characteristics of Shahezi Formation beneath the Well SK-2 and its periphery: An analysis of logging and seismic data. Geology in China, 46(5): 1052-1060 (2019). (in Chinese with English abstract).

9. Song Yan, Dai Jinxing, Li Xianqi, etal. Main geochemical and geological characteristics of large and medium-sized gas fields in China [J]. Acta petrolei sinica, 1998,19(1) : $1 \sim 5$.

10. Fu G., Zang F. Z., Favorable geological conditions for Formation of Xushen large gas field. [J]. Journal of Jilin University (Earth Science Edition), ,41(1):1220 (2011).

11. Nie H. K., Zhang J.C., Li Y.X., Accumulation conditions of the Lower Cambrian shale gas in the Sichuan Basin and its periphery [J]. Acta Petrolei Sinica, 32(6):959-967 (2011).

12. Zou C.N., Tao S. Z., Zhu R. K., etal, Formation and distribution of "continuous" gas reservoirs and their giant gas province:A case from the Upper Triassic Xujiahe Formation giant gas province, Sichuan Basin 
[J].Petroleum Exploration and Development, 36(3):307-319 (2009).

13. Yang S.Y., Zhang J. C., Tang X., Three-dimensional basin modeling study on Zhangjiatan shale gas area in Ordos Basin [J]. Natural Gas Geoscience, 27(5):932-942 (2016).

14. Wang S. J., Wang L.S., Huang J. L., etal, Accumulation conditions of shale gas reservoirs in Silurian of the Upper Yangtze Region [J]. Natural Gas Industry,29(5):45-50 (2009).

15. Guan D. S., Niu J. Y., Guo L., Unconventional Petroleum geology in China [M]. Beijing:Petroleum Industry Press (1995).

16. Zhang J. C., Jiang S.L., Tang X., etal, Accumulation types and resources characteristics of shale gas in China [J]. Natural Gas Industry, 29(12):109-114 (2009). 